\title{
Evaluation of the Motivation Status of Enterprises and Higher Vocational Schools Participating in Modern Apprenticeship and Its Key Influencing Factors Based on Artificial Neural Network
}

https://doi.org/10.3991/ijet.v16i08.22133

Shu Ji

Zhejiang Dongfang Polytechnic, Wenzhou, China

Jun $\mathrm{Li}^{(凶)}$

Wenzhou Polytechnic, Wenzhou, China

wenzhi2017@wzvtc.edu.cn

\begin{abstract}
During the reform of talent training mode, higher vocational schools must promote and apply modern apprenticeship to meet the needs of intelligent manufacturing. However, most enterprises and schools differ greatly in the participation enthusiasm and implementation motivation for modern apprenticeship. To enhance the participation motivation, it is critical to correctly evaluate the motivation status of enterprises and schools participating in modern apprenticeship, and analyze its key influencing factors. For this reason, this paper employs the Artificial Neural Network (ANN) to evaluate such motivation status. Firstly, a Modern Apprenticeship Motivation Status (MAMS) evaluation model was established, along with its evaluation index system (EIS). Then, differences in the motivation status were compared from seven aspects. After that, an improved backpropagation (BP) neural network was built to construct and optimize the MAMS prediction model. Finally, the constructed model was proved valid through experiments.
\end{abstract}

Keywords-Backpropagation (BP) neural network, modern apprenticeship, motivation status evaluation, influencing factor analysis

\section{Introduction}

In recent years, China's economic structure transformation has accelerated. Knowledgeable, skilled, creative, and high-quality talents are the indispensable and irreplaceable strategic elements and key supports for the economic structure transformation of China, and therefore, the cultivation of such talents has received the attention from the Chinese government and various schools in the country [1-4]. In 2014 and 2015, the Ministry of Education, and the Ministry of Human Resources and Social Security successively issued a few important documents such as Opinions on Carrying out Pilot Works of Modern Apprenticeship and Notice on Carrying out Pilot Works of New 
Enterprise Apprenticeship. After that, 68 modern apprenticeship pilot units had been determined [5-8]. In the context of intelligent manufacturing, the research on the promotion and application of modern apprenticeship is a necessity for laying a theoretical basis for the construction of high-quality talent training mode and for reforming the talent training mode of modern higher vocational schools.

For existing literatures concerning the topic of modern apprenticeship, they mainly studied from the aspects of implementation status, implementation experience, and training mode optimization, etc. [9-14]. An example is that Wiemann [15] analyzed the policy orientation and practical basis of the training mode of modern apprenticeship, and sorted out problems existing in the implementation of modern apprenticeship such as the non-uniform school-enterprise talent training mechanisms, unreasonable master selection system in enterprises, incomplete teaching standard system, and the poor teaching quality management, etc.; then, the study proposed a few improvement measures such as optimize talent training schemes, improve the teaching organization management, and enhance faculty construction, etc. Also, there are papers studied the economic value of the four parties of government, schools, enterprises, and apprentices in the implementation of modern apprenticeship [16-18]. For example, Neugebauer et al. [19] discussed the practical value of these parties in depth, and proposed to provide a good environment for the learning of practical knowledge and skills, so as to promote the transfer of knowledge and skills to the actual workplace, and promote the iteration and innovation of knowledge and skills. Vossen [20] elaborated on the feasibility of applying modern apprenticeship to the secondary and higher vocational education, by comparing with the German national professional standards, and the experiences in talent training scheme formulation, connective strategy formulation, connective course development, and enterprise enthusiasm motivation, etc., the study proposed suitable guidance for the connection between secondary and higher vocational education in China. Susanne [21] carried out research on the moral education strategy of modern apprenticeship; based on the feasibility analysis of the training goals, methods, and modes of modern apprenticeship, the study proposed to learn from local talent training demonstrations and implement specific training courses, systems, and strategies. Based on the modern apprenticeship, Griesbaum et al. [22] constructed a training mode for the cultivation of senior professionals of hardware and electromechanical majors, with Feijian co. ltd. as an example, the study verified the effectiveness of the constructed 6T model, and elaborated to use the "enterprise selection - scheme determination - course construction - principle compliance - faculty expansion - resource integration" mode to implement the digital, networked and intelligent process. Ratnasingam and Ioras [23] emphasized that, under the background that the traditional manufacturing industry is transforming towards the intelligent, digital, networked, and high-end direction, and the talent training mode of traditional apprenticeship needs to be updated; for this reason, their study proposed the necessity and feasibility of promoting modern apprenticeship in the intelligent manufacturing field.

The participation enthusiasm of enterprises and higher vocational schools is the condition for the promotion of modern apprenticeship. Survey results showed that, the participation enthusiasm and implementation motivation of enterprises and schools are of very different degrees and levels. In order to achieve better promotion effect of modern 
apprenticeship, it is necessary to strengthen the participation motivation of enterprises and schools and correctly evaluate their status. Therefore, this paper analyzed the corresponding influencing factors, and made use of ANN's advantage in complex information data processing to evaluate such motivation status.

The main content of this paper is arranged as follows: the second part constructed the MAMS evaluation model and the EIS, and introduced the evaluation indexes in detail; the third part compared the differences in the motivation status from the 7 aspects of skill level, job organization and division, production organization form, job position adaptability, training benefits, labor attributes, and awareness and inheritance; the fourth part constructed and optimized the MAMS prediction model based on an improved BP neural network; the fifth part verified the effectiveness of the constructed MAMS prediction model with experimental results; the last part is conclusion.

\section{MAMS Evaluation Model and its EIS}

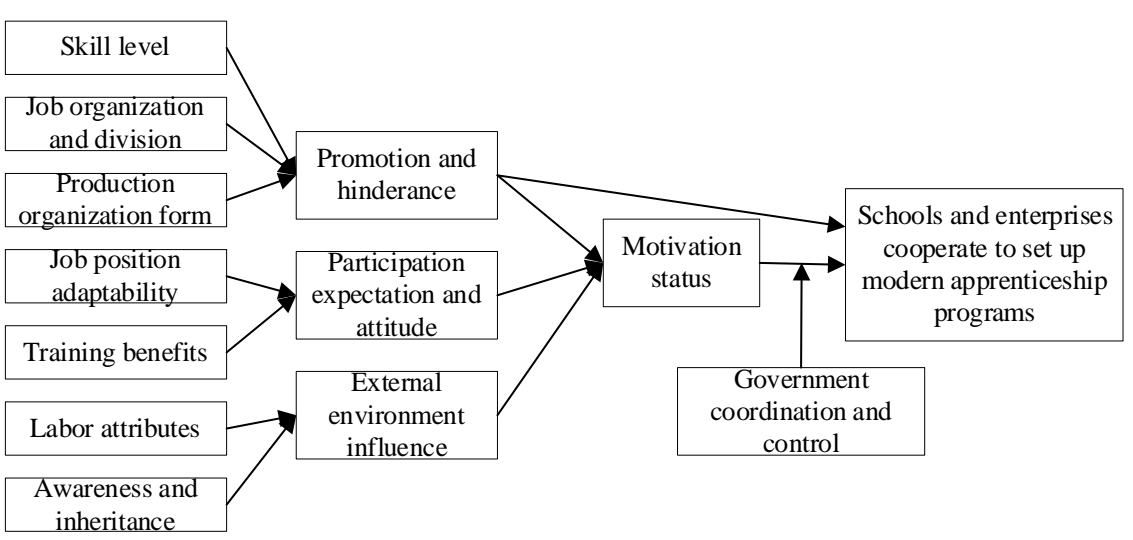

Fig. 1. Influencing factors of motivation status

To investigate the motivation status of enterprises participating in modern apprenticeship programs, the research should start with the influencing factors of motivation status. This paper discussed it from three aspects: the promotion and hinderance factor, the participation expectation and attitude factor, and the external environment factor. Figure 1 gives the influencing factors of the constructed MAMS evaluation model.

In terms of the promotion and hinderance factor, the motivation status of enterprises participating in modern apprenticeship is stronger in case of more diversified production tasks, more complex production process, higher technical level, wider apprentice job scopes, higher work division and collaboration level of production process, higher professional and scale level of batch production, and more emphasis is laid on lean production. In terms of the participation expectation and attitude factor, the motivation status of enterprises participating in modern apprenticeship is stronger when the enterprise realizes that modern apprenticeship could cultivate apprentices who are qualified to different job positions flexibly, the enterprise could obtain higher production values 
than their input in apprentice training, and the work ability and qualities of trained apprentices are better than workers recruited from outside. In terms of the external environment factor, the motivation status of enterprises participating in modern apprenticeship is stronger when they could not obtain sufficient talent supply from outside talent market, the separation rate and employment rate cannot reach a balance, or they have certain awareness for social responsibility and traditional apprenticeship inheritance. Table 1 gives the evaluation indexes of the motivation status.

Table 1. Evaluation indexes of motivation status

\begin{tabular}{|c|c|c|c|}
\hline $\begin{array}{l}\text { First-level eval- } \\
\text { uation index }\end{array}$ & $\begin{array}{c}\text { Second-level } \\
\text { evaluation index }\end{array}$ & Index dimension & Index description \\
\hline \multirow{4}{*}{ Skill level } & Target product type & Diverse, standard & Particularity of production tasks \\
\hline & $\begin{array}{l}\text { Target product } \\
\text { production technique }\end{array}$ & Complex, simple & Complexity of production techniques \\
\hline & $\begin{array}{l}\text { Technical level of target } \\
\text { product production }\end{array}$ & High, low & $\begin{array}{l}\text { Comprehension of production process or } \\
\text { equipment operating principle }\end{array}$ \\
\hline & Skill training period & Long, short & The training requires a certain period \\
\hline \multirow{2}{*}{$\begin{array}{l}\text { Job organization } \\
\text { and division }\end{array}$} & Job responsibility & Narrow, wide & Work content and responsibility \\
\hline & Work scope & Narrow, wide & The scope of work \\
\hline \multirow{2}{*}{$\begin{array}{l}\text { Production } \\
\text { organization } \\
\text { form }\end{array}$} & $\begin{array}{l}\text { Collaborative } \\
\text { production }\end{array}$ & $\begin{array}{l}\text { Large-scale batch } \\
\text { production }\end{array}$ & $\begin{array}{l}\text { Collaborate with others to produce } \\
\text { standardized products and take partial } \\
\text { quality responsibility }\end{array}$ \\
\hline & Lean production & $\begin{array}{l}\text { Small-scale custo } \\
\text { mized production }\end{array}$ & $\begin{array}{l}\text { Independently produce customized } \\
\text { product and take all quality responsibility }\end{array}$ \\
\hline \multirow{2}{*}{$\begin{array}{l}\text { Job position } \\
\text { adaptability }\end{array}$} & Work ability & Strong, weak & $\begin{array}{l}\text { Be qualified to different job positions } \\
\text { flexibly }\end{array}$ \\
\hline & Practical experience & Have, have not & $\begin{array}{l}\text { Have practical work experience of } \\
\text { different job positions }\end{array}$ \\
\hline \multirow{2}{*}{$\begin{array}{l}\text { Training } \\
\text { benefits }\end{array}$} & $\begin{array}{l}\text { Compare training input } \\
\text { and production value }\end{array}$ & Large, small & $\begin{array}{l}\text { Compare the production value created by } \\
\text { the trained apprentices and the input in } \\
\text { apprentice training }\end{array}$ \\
\hline & $\begin{array}{l}\text { Compare the quality } \\
\text { of apprentices and } \\
\text { recruited workers }\end{array}$ & High, low & $\begin{array}{l}\text { Compare the work ability and professional } \\
\text { quality of trained apprentices and workers } \\
\text { recruited from outside }\end{array}$ \\
\hline \multirow{3}{*}{$\begin{array}{l}\text { Labor } \\
\text { attributes }\end{array}$} & Age structure & $\begin{array}{l}\text { Reasonable, } \\
\text { unreasonable }\end{array}$ & Age structure is stable, no aging problem \\
\hline & $\begin{array}{l}\text { Separation rate and } \\
\text { employment rate }\end{array}$ & High, low & Influence of employee mobility \\
\hline & Talent demand & $\begin{array}{l}\text { Insufficient, } \\
\text { sufficient }\end{array}$ & Is high-quality talent reserve sufficient? \\
\hline \multirow{2}{*}{$\begin{array}{l}\text { Awareness } \\
\text { and } \\
\text { inheritance }\end{array}$} & $\begin{array}{l}\text { Social responsibility } \\
\text { awareness }\end{array}$ & Take, take not & $\begin{array}{l}\text { The awareness of enterprises and schools } \\
\text { to take social responsibility }\end{array}$ \\
\hline & $\begin{array}{l}\text { Traditional apprentice } \\
\text { ship inheritance }\end{array}$ & $\begin{array}{l}\text { Inherit, inherit } \\
\text { not }\end{array}$ & $\begin{array}{l}\text { Does the enterprise train core technicians } \\
\text { independently }\end{array}$ \\
\hline
\end{tabular}

From the above analysis, when enterprises cannot recruit enough high-quality employees from outside, they tend to participate in modern apprenticeship. When the production requirement, job organization and division, and production organization form of enterprises raise talent demand, they would change their talent requirement levels. The transition from school education to enterprise work practice requires the 
government to impose macro restrictions on the modern apprenticeship education. If the benefits of each enterprise could be ensured, the collaboration of enterprises and higher vocational schools in modern apprenticeship could be achieved; at the same time, it can also be regarded as a manifestation of the integration of skill training, social responsibility, and technique inheritance.

\section{Comparison of Differences in Motivation Status}

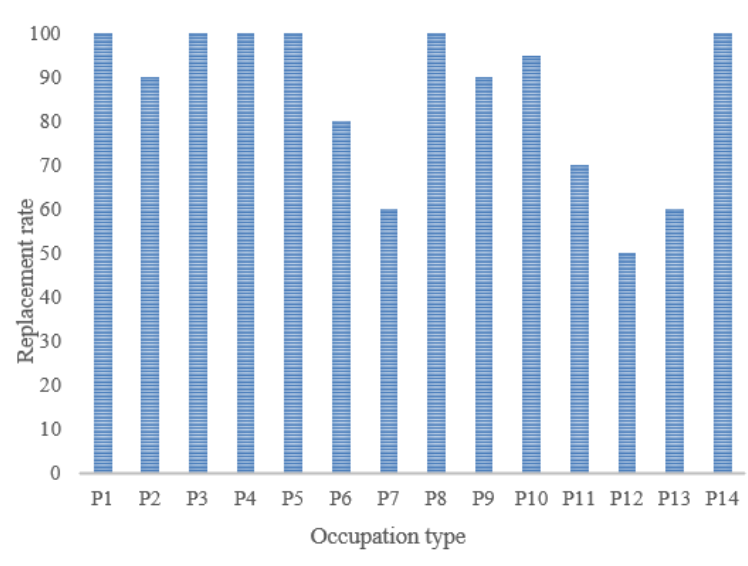

Fig. 2. Replacement rate of different occupations

Figure 2 shows the replacement rate of 14 different occupations such as cleaning, catering services, picking, copywriting, printing, telephone operating, equipment operating and maintaining, driving, cargo handling, basic management, mining assistance, manual assembly, and delivering, etc. As can be seen from the figure, compared with occupations that do not require special professional training, for mining assistance, equipment operating and maintaining and other occupations that require continuous vocational training, the replacement rate of these occupations is relatively low, however, there is still a risk of being replaced by computers or artificial intelligence technologies. Based on above analysis, having a good job position adaptability is a requirement of enterprises for qualified technicians, and it is also a manifestation of the irreplaceable value of trained apprentices. Table 2 shows the comparison of the motivation status based on job position adaptability, and it proposed the training goals and requirements for apprentices and enterprises participating in modern apprenticeship.

Figure 3 summarizes the input costs of different types of education in China. According to the figure, the input cost of modern apprenticeship is 10,600 yuan, which is even higher than that of undergraduate education. Although the input cost is relatively high, we cannot ignore the production values brought by the trained apprentices. Table 3 gives the details of the input and output of the training mode of modern apprenticeship. According to the table, the average annual output of the enterprise is 1548.4 yuan, except for the 6-th semester (when apprentices need to take some time to obtain the vocational certificate), from the 1 -st semester to the 5 -th semester, the production value 
created by the apprentices increases gradually; in the 3-rd semester, the production value exceeds the enterprise's training input; and the value reaches the maximum in the 5-th semester.

Table 2. Comparison of differences in motivation status based on job position adaptability

\begin{tabular}{|c|c|}
\hline \multicolumn{2}{|c|}{ Job position adaptability } \\
\hline Motivation status is weak & Motivation status is strong \\
\hline $\begin{array}{l}\text { Professional and occupational definitions are } \\
\text { confusing }\end{array}$ & Professional and occupational definitions are clear \\
\hline $\begin{array}{l}\text { There is no uniform criterion for training effect } \\
\text { evaluation }\end{array}$ & The evaluation criteria of qualified technicians are clear \\
\hline $\begin{array}{l}\text { More cases require to fix positions, personnel, } \\
\text { and duties }\end{array}$ & Job position shift regulations are more restrictive \\
\hline Job position adaptability for 3-4 positions & Job position adaptability for more than 5 positions \\
\hline $\begin{array}{l}\text { Can hardly guarantee work quality, skill profi- } \\
\text { ciency, and work efficiency }\end{array}$ & $\begin{array}{l}\text { Can cultivate ability to innovate manufacturing technique } \\
\text { and process, enhance understanding of occupations and } \\
\text { work requirements }\end{array}$ \\
\hline
\end{tabular}

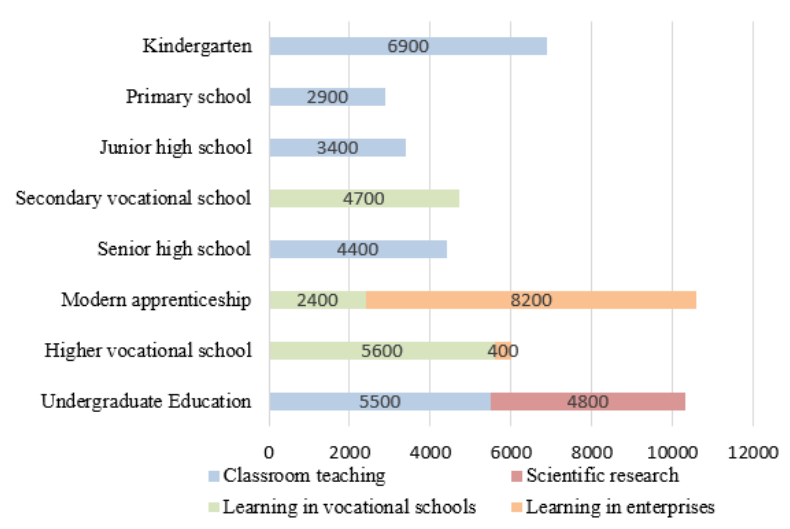

Fig. 3. Input costs of different types of education in China in 2019

Table 3. Input-output of modern apprenticeship training

\begin{tabular}{|l|c|c|c|}
\hline \multicolumn{1}{|c|}{ Training input-output } & Training input & Production value & Training output \\
\hline Annual average value & 12806.1 & 14574.4 & 1548.4 \\
\hline Total training & 38418.4 & 43723.3 & 5304.9 \\
\hline Semester 1 & 6872.9 & 5763.5 & -1109.4 \\
\hline Semester 2 & 7121.6 & 7043.9 & -77.7 \\
\hline Semester 3 & 7438.3 & 7853.1 & 414.8 \\
\hline Semester 4 & 6946.7 & 8927.6 & 1980.9 \\
\hline Semester 5 & 5275.4 & 9012.8 & 3737.4 \\
\hline Semester 6 & 4763.5 & 5122.4 & 358.9 \\
\hline
\end{tabular}


Table 4. Comparison of differences in motivation status based on training output

\begin{tabular}{|c|c|}
\hline \multicolumn{2}{|l|}{ Training output } \\
\hline Motivation status is weak & Motivation status is strong \\
\hline $\begin{array}{l}\text { Schools believe that enterprises are the main responsible party of } \\
\text { modern apprenticeship }\end{array}$ & $\begin{array}{l}\text { Obtain qualified technicians that best } \\
\text { meet the actual production needs of the } \\
\text { enterprise }\end{array}$ \\
\hline $\begin{array}{l}\text { Enterprises believe that students and higher vocational schools are } \\
\text { the main benefited parties of modern apprenticeship }\end{array}$ & $\begin{array}{l}\text { Obtain production value during the } \\
\text { apprentice training period }\end{array}$ \\
\hline $\begin{array}{l}\text { Enterprises do not recognize the ability of technicians trained by } \\
\text { modern apprenticeship }\end{array}$ & $\begin{array}{l}\text { Avoid spending too much in recruiting } \\
\text { qualified technicians }\end{array}$ \\
\hline Enterprises recruit technicians from outside & $\begin{array}{l}\text { Enterprises have high recognition of } \\
\text { the ability of apprentices }\end{array}$ \\
\hline Enterprises have low recognition of the ability of apprentices & $\begin{array}{l}\text { More reserves of high-quality skilled } \\
\text { talents }\end{array}$ \\
\hline $\begin{array}{l}\text { Enterprises believe there's a large gap between training input and } \\
\text { output. }\end{array}$ & \\
\hline $\begin{array}{l}\text { Non-state-owned and small-and-medium sized enterprises believe } \\
\text { that the input in training is too much }\end{array}$ & \\
\hline Few reserves of high-quality skilled talents & \\
\hline
\end{tabular}

Table 5. Comparison of differences in motivation status based on awareness and inheritance

\begin{tabular}{|c|c|}
\hline \multicolumn{2}{|c|}{ Awareness and inheritance } \\
\hline Motivation status is weak & Motivation status is strong \\
\hline $\begin{array}{l}\text { State-owned enterprises have a strong sense of social } \\
\text { responsibility }\end{array}$ & $\begin{array}{l}\text { More attention is given to the apprentice's } \\
\text { personal interests and professionalism }\end{array}$ \\
\hline Lack of inheritance of traditional techniques and skills & A strong sense of school-enterprise cooperation \\
\hline $\begin{array}{l}\text { There're independent apprenticeship systems in the } \\
\text { enterprises }\end{array}$ & $\begin{array}{l}\text { A strong sense of traditional techniques and skills } \\
\text { inheritance }\end{array}$ \\
\hline $\begin{array}{l}\text { More attention is given to the apprentice's character and } \\
\text { family background }\end{array}$ & $\begin{array}{l}\text { Strong awareness and ability to update and } \\
\text { optimize traditional techniques and skills }\end{array}$ \\
\hline
\end{tabular}

The motivation of enterprises to participate in the modern apprenticeship is affected by the training input-output calculation and other factors. Table 4 shows the comparison of differences in the motivation status based on training output, it lists training references from multiple aspects such as input-output, quality, and degree of recognition, etc. In other words, the expected training effect of modern apprenticeship is to meet enterprises' requirements in talents and training output.

Tables 5 and 6 respectively give comparison of differences in motivation status based on awareness and inheritance and based on labor attributes. From the aspects of technology and skill inheritance awareness, social responsibility awareness, talent supply and demand, and talent turnover rate of different enterprises and industries, they emphasized the social roles the enterprises need to play and the talent supply and demand status the enterprises need to achieve during the process of modern apprenticeship training system construction on the premise of guaranteeing the interest of the enterprises.

Table 7 shows the comparison of differences in the motivation status based on skill level, job organization and division, and production organization form. These three aspects are all factors of the enterprise's internal controlled motivation, they reflect the 
most objective and real status of the motivation of enterprises. At present stage, the developing trend of domestic enterprises is to produce products with high added values, which has resulted in more skilled and specialized features of job division and production organization. In contrast to the existing work mode with mature and fine job divisions and skilled operation in fixed positions, if an enterprise is developing towards the direction of wider-range job divisions and avoiding extreme production/work organization forms, then the enterprise would have a stronger motivation to participate in modern apprenticeship.

Table 6. Comparison of differences in motivation status based on labor attributes

\begin{tabular}{|c|c|}
\hline \multicolumn{2}{|c|}{ Labor attributes } \\
\hline Motivation status is weak & Motivation status is weak \\
\hline Age structure is stable, no aging problem & Age structure is relatively old \\
\hline $\begin{array}{l}\text { The employment pressure of higher vocational school } \\
\text { students is relatively large }\end{array}$ & $\begin{array}{l}\text { Separation rate and employment rate are in a } \\
\text { balanced state }\end{array}$ \\
\hline $\begin{array}{l}\text { The quality level of talents in the talent market is quite } \\
\text { different but can basically meet the talent demand. }\end{array}$ & $\begin{array}{l}\text { Graduates have stronger desire for further } \\
\text { studies }\end{array}$ \\
\hline $\begin{array}{l}\text { The influencing factors of separation rate and employment } \\
\text { rate are complicated }\end{array}$ & $\begin{array}{l}\text { Have no difficulty in student enrollment, no } \\
\text { student quality problem }\end{array}$ \\
\hline Graduates have stronger desire for further studies & $\begin{array}{l}\text { Apprentices have less employment pressure; } \\
\text { their salary level is relatively high }\end{array}$ \\
\hline $\begin{array}{l}\text { Higher vocational schools have more difficulties in student } \\
\text { enrolment than colleges and universities }\end{array}$ & \\
\hline $\begin{array}{l}\text { Student enrolment quality of higher vocational schools is } \\
\text { not good }\end{array}$ & \\
\hline
\end{tabular}

Table 7. Comparison of differences in motivation status based on skill level, job organization and division, and production organization form

\begin{tabular}{|l|l|}
\hline \multicolumn{2}{|c|}{ Skill level, job organization and division, and production organization form } \\
\hline \multicolumn{1}{|c|}{ Motivation status is weak } & \multicolumn{1}{c|}{ Motivation status is weak } \\
\hline $\begin{array}{l}\text { Low product added value } \\
\text { Have diversified and standardized products at the } \\
\text { same time }\end{array}$ & $\begin{array}{l}\text { The products are of higher diversity and complexity } \\
\text { level }\end{array}$ \\
\hline $\begin{array}{l}\text { Fine divisions of job responsibilities and work } \\
\text { scopes }\end{array}$ & $\begin{array}{l}\text { Wide divisions of job responsibilities and work } \\
\text { scopes }\end{array}$ \\
\hline $\begin{array}{l}\text { Low-level understanding of production process or } \\
\text { equipment operating principle }\end{array}$ & Avoid extreme production/work organization forms \\
\hline Short training period & Long training period \\
\hline Too simple training content & Flexible training content \\
\hline
\end{tabular}

\section{Construction and Optimization of MAMS Prediction Model}

\subsection{Model construction}

This paper employed an improved BP neural network to evaluate the motivation status. The overall idea is that, for $N$ input learning samples of motivation status factors $I^{1}, I^{2}, \ldots, I^{N}$, there are corresponding output results of the motivation status $\hat{O}^{1}, \hat{O}^{2}, \ldots, \hat{O}^{M}$. 
The network training process is to make the actual output $O^{1}, O^{2}, \ldots, O^{M}$ to get closer to the target output $\hat{O}^{1}, \hat{O}^{2}, \ldots, \hat{O}^{M}$ by continuously adjusting and updating the weight and threshold of the network, and at this time, the evaluation accuracy of the network is higher. If the actual output of the network is not close enough to the target output, it is necessary to calculate the network evaluation error and propagate it back in the network until the adjusted weight and threshold can make the error meet the requirement. Figure 4 is a diagram of the structure of the constructed neural network.

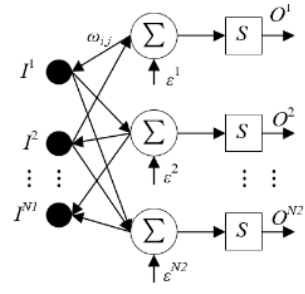

a)

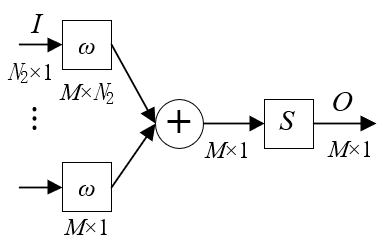

b)

Fig. 4. Structure of the constructed BP neural network

The output of the $i$-th neuron node in the hidden layer of the network can be calculated by Formula 1:

$$
O_{i}^{1}=f^{1}\left(\sum_{j=1}^{N_{1}} \omega_{i j}^{1} I_{j}+\varepsilon_{i}^{1}\right)
$$

The output of the $l$-th neuron node in the output layer of the network can be calculated by Formula 2:

$$
O_{l}^{2}=f^{2}\left(\sum_{i=1}^{N_{2}} w_{l i}^{2} O_{i}^{1}+\varepsilon_{l}^{2}\right)
$$

Formula 3 is the evaluation error function of the network:

$$
\operatorname{Error}(\omega, \varepsilon)=\frac{1}{2} \sum_{l=1}^{N_{2}}\left(\hat{O}_{l}^{2}-O_{l}^{2}\right)^{2}
$$

The gradient descent method was used to back-propagate the network evaluation error. The weight change from the $j$-th input of the input layer to the $i$-th output of the hidden layer can be adjusted by Formula 4: 


$$
\begin{aligned}
& \Delta \omega_{i j}^{1}=-\lambda \frac{\partial \text { Error }}{\partial \omega_{i j}^{1}} \\
& =-\lambda \frac{\partial E r r o r}{\partial O_{l}^{2}} \cdot \frac{\partial O_{l}^{2}}{\partial O_{i}^{2}} \cdot \frac{\partial O_{i}^{2}}{\partial \omega_{i j}^{1}} \\
& =\lambda \sum_{k=1}^{s 2}\left(\hat{O}_{l}^{2}-O_{l}^{2}\right)\left(f^{2}\right)^{\prime} \cdot \omega_{k i}^{1} \cdot\left(f^{1}\right)^{\prime} \cdot I_{j}=\lambda \cdot v_{i j} \cdot I_{j}
\end{aligned}
$$

The corresponding threshold change can be adjusted by Formula 5:

$$
\Delta \varepsilon_{i j}^{1}=\lambda_{i j}
$$

The weight change from the $i$-th input of the hidden layer to the $l$-th output of the output layer can be adjusted by Formula 6:

$$
\begin{aligned}
& \Delta \omega_{l i}^{2}=-\lambda \frac{\partial E \text { Eror }}{\partial \omega_{l i}^{2}} \\
& =-\lambda \frac{\partial E r r o r}{\partial O_{l}^{2}} \cdot \frac{\partial O_{l}^{2}}{\partial \omega_{l i}^{2}}=\lambda\left(\hat{O}_{l}^{2}-O_{l}^{2}\right)\left(f^{2}\right)^{\prime} \cdot O_{i}^{1}=\lambda \cdot v_{l i} \cdot O_{i}^{1}
\end{aligned}
$$

The corresponding threshold change can be adjusted by Formula 7:

$$
\begin{aligned}
& \Delta \varepsilon_{l i}^{2}=-\lambda \frac{\partial \text { Error }}{\partial \varepsilon_{l i}^{2}}=-\lambda \frac{\partial \text { Error }}{\partial O_{l}^{2}} \times \frac{\partial O_{l}^{2}}{\partial \varepsilon_{l i}^{2}} \\
& =\lambda\left(\hat{O}_{l}^{2}-O_{l}^{2}\right)\left(f^{2}\right)^{\prime}=\lambda \cdot v_{l i}
\end{aligned}
$$

The calculation of Formulas 1-7 can be realized by calling the corresponding functions in MATLAB.

\subsection{Model optimization}

BP neural network showed high fault tolerance and good self-learning ability when evaluating the motivation status of modern apprenticeship, however, there's still limitations of low efficiency due to the use of the gradient descent method. At the same time, during the actual network learning based on learning samples of motivation factors, situations such as falling into the local minimum is inevitable, and the search for the global optimal solution becomes harder. In addition, currently, the number of neurons in the hidden layer and the learning rate are still determined by empirical formulas. Aiming at the local optimal solution problem of the network, this paper added a value proportional to the change of weight and threshold in the previous iteration (shown as Formula 8) to the change of weight and threshold: 


$$
\left\{\begin{array}{c}
\Delta \omega_{i j}(l+1)=(1-\tau) \lambda v_{i} I_{j}+\tau \Delta \omega_{i j}(l) \\
\Delta \varepsilon_{i}(l+1)=(1-\tau) \lambda v_{i}+\tau \Delta \varepsilon_{i}(l)
\end{array}\right.
$$

where, $\tau$ is the momentum factor that plays a transfer role when the weight and threshold are adjusted for the last time. According to the formula, the small fluctuations in network evaluation errors will lead to small values of $v_{i j}$ and $v_{l i}$, so the change of weight and threshold of two successive iterations are almost the same, which has avoided the adverse effects of zero changes. To ensure there will be no substantial increase in network errors, the error change rate of $\tau$ needs to be constrained.

$$
\tau=\left\{\begin{array}{l}
0, \quad \alpha_{E R}(l)>1.03 \times \alpha_{E R}(l-1) \\
0.96, \quad \alpha_{E R}(l)<\alpha_{E R}(l-1) \\
\tau, \quad \text { Other situations }
\end{array}\right.
$$

In view of the situation that taking the mean square error as the loss function has caused too-slow parameter update speed and hindered the network training, this paper used the cross-entropy function shown as Formula 10 to replace the mean square error:

$$
C E=-\frac{1}{Q} \sum[O \ln x+(1-O) \ln (1-x)]
$$

Compared with mean square error, the cross-entropy function has the advantage that it could effectively prevent the decrease in learning speed. $x=\eta(c)$ represents the chain rule when obtaining the partial derivative of the loss function to the weight, then the error of the output evaluation result can be expressed by $\eta(c)-O$. Assume $\omega_{k}$ is the weight vector of each layer, then Formula 11 gives the calculation of the partial derivative of the cross-entropy function to the weight:

$$
\begin{aligned}
& \frac{\partial C E}{\partial \omega_{k}}=-\frac{1}{Q} \sum_{I}\left(\frac{O}{\eta(c)}-\frac{1-O}{1-\eta(c)}\right) \frac{\partial \eta}{\partial \omega_{k}} \\
& =-\frac{1}{Q} \sum_{I}\left(\frac{O}{\eta(c)}-\frac{1-O}{1-\eta(c)}\right) \eta^{\prime}(c) I_{k}
\end{aligned}
$$

The formula can be simplified to:

$$
\frac{\partial C E}{\partial \omega_{k}}=-\frac{1}{Q} \sum_{I} \frac{\eta^{\prime}(c) I_{k}}{\eta(c)[1-\eta(c)]}[\eta(c)-O]
$$

If the sigmoid function is selected as the activation function, then there is:

$$
\eta^{\prime}(c)=\eta(c)[1-\eta(c)]
$$

By substituting it into Formula 12 we can get:

$$
\frac{\partial C E}{\partial \omega_{k}}=-\frac{1}{Q} \sum_{I} I_{k}[\eta(c)-O]
$$


According to above formula, the learning speed of $\omega_{k}$ changes proportionally with the change of $\eta(c)-O$. Since there is no partial derivative term of $\eta(c)$ in the equation, the decrease of the learning speed is effectively avoided. Similarly, for threshold, there is:

$$
\frac{\partial C E}{\partial \varepsilon_{k}}=-\frac{1}{Q} \sum_{I}[\eta(c)-O]
$$

Aiming at the selection of the network learning speed $\lambda$, this paper adopted the adaptive optimization shown as Formula 16:

$$
\lambda(l+1)=\left\{\begin{array}{l}
0.75 \lambda(l), \quad \alpha_{E R}(l+1)>1.03 \times \alpha_{E R}(l) \\
1.04 \lambda(l), \quad \alpha_{E R}(l+1)<\alpha_{E R}(l) \\
\lambda(l), \quad \text { Other situations }
\end{array}\right.
$$

Through the optimization of the above formula, the network training frequency and training time can be reduced, and the training efficiency can be improved.

\section{$5 \quad$ Experimental Results and Analysis}

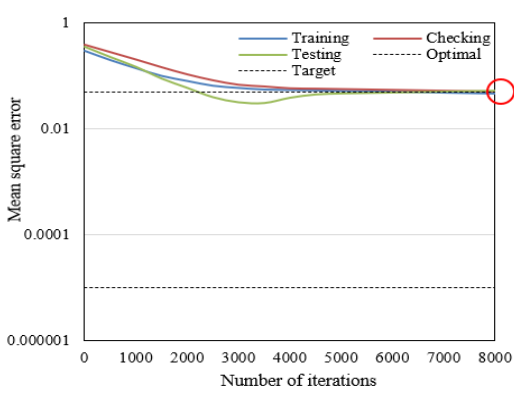

a)

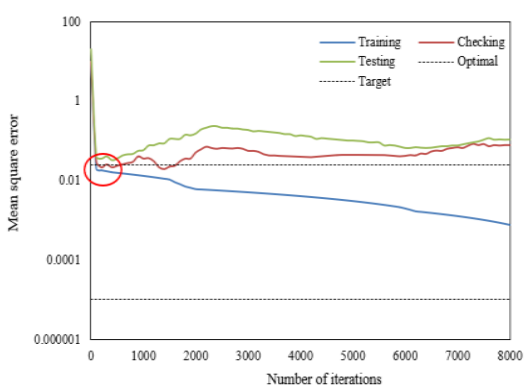

b)

Fig. 5. Training error of BP neural network before and after optimization 


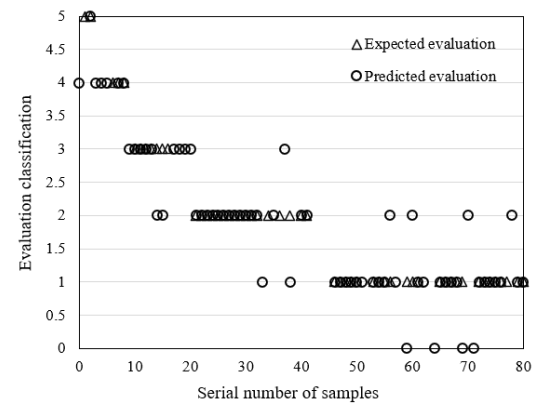

a)

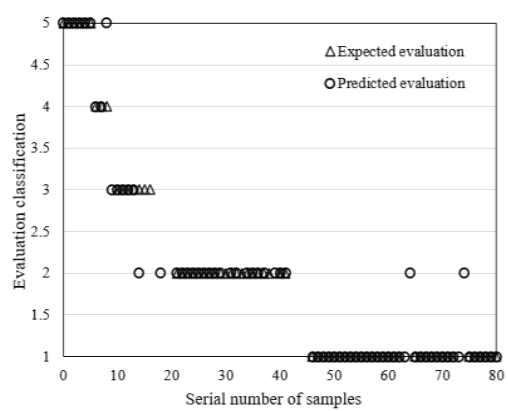

b)

Fig. 6. Predicted category of BP neural network before and after optimization

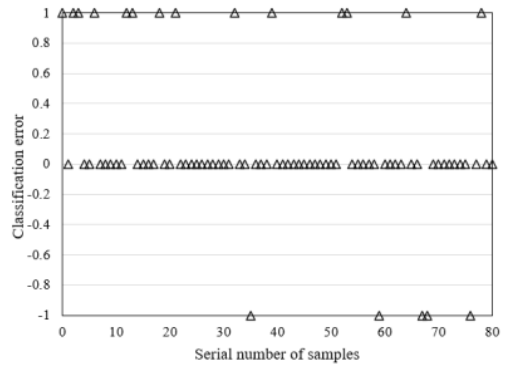

a)

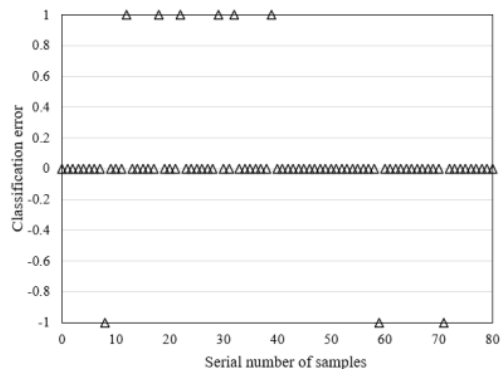

b)

Fig. 7. Classification error of BP neural network before and after optimization

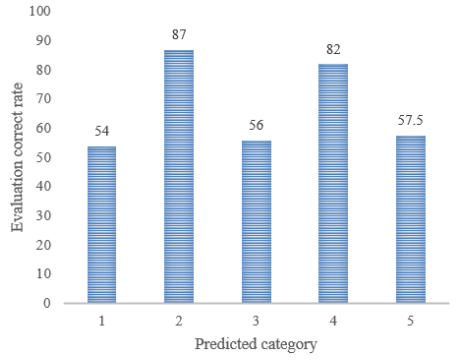

a)

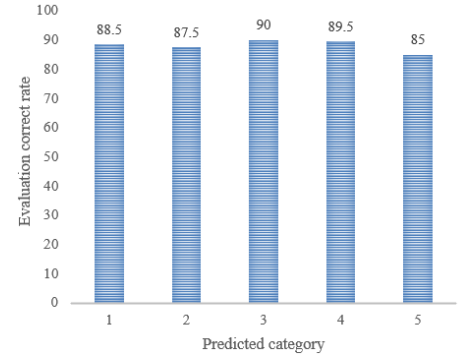

b)

Fig. 8. Correct rate of predicted category of BP neural network before and after optimization 
This paper constructed a BP neural network to evaluate the motivation status of modern apprenticeship; to verify the effectiveness of the constructed network, this study designed the relevant comparative experiment. In the experiment, random numbers within $[-1,1]$ were generated and assigned to the initial weight and threshold of the network, the preset accuracy of the network was set to be $1 \times 10^{-5}$, and the maximum number of iterations was 8000 . The experiment selected 230 sets of evaluation index data of motivation status of 10 different enterprises participating in modern apprenticeship in different time periods, including 150 sets of training samples and 80 sets of test samples. The network construction, training and testing were all performed in MATLAB.

Figures 5 (a) and 5(b) respectively show the training error curves of the BP neural network before and after the optimization. It can be seen from the figure that, before optimization, the training of the BP neural network did not stop until the maximum number of iterations was reached; after optimization, when the number of iterations was 50 , the mean square error of the network reached the optimal state of 0.04521 , which had verified the good convergence performance of the network.

Figures 6 (a) and 6(b) respectively show the prediction category of BP neural network before and after optimization. As shown in the figure, the triangles represent the expected rating of the motivation status, and the circles represent the predicted rating of the motivation status in the experiment. When the triangles and circles are completely overlapped, it means that the expected rating is consistent with the predicted rating; if the triangles and circles are not completely overlapped, it means there're errors between the expected and predicted rating. According to the figure, for most test samples, the predicted rating was consistent, only a few samples showed errors, and the error of the predicted rating of the optimized network was even smaller.

Figures 7 (a) and 7(b) respectively show the classification error of the BP neural network before and after the optimization. The cross-entropy function value represents the difference between the accurate value and the predicted value of the evaluation of motivation status. According to the figure, out of the 80 sets of evaluation index data samples, the predicted results of 72 sets were consistent with the actual situations, after optimization, the classification accuracy of 61 sets had been greatly improved; as for the remaining 8 sets, the error value fluctuated within $[-1,1]$, that is, the error of predicted category was less than or equal to a certain level.

Figures 8 (a) and 8(b) respectively show the correct rate of predicted category of the BP neural network before and after optimization. According to the figure, after optimization, the correct rate increased from $67.3 \%$ to $88.1 \%$, and the correct rate of category 3 reached $90 \%$, which had verified the effectiveness of the proposed BP neural network optimization strategy. The constructed network showed good performance in fault tolerance and prediction accuracy in the prediction evaluation process of the motivation status of modern apprenticeship. 


\section{Conclusion}

In order to promote the participation motivation of enterprises and schools and correctly evaluate the motivation status, this paper analysed the influencing factor of motivation status and used ANN to evaluate the motivation status. Then, based on the constructed MAMS evaluation model and the corresponding EIS, the differences in the motivation status were analysed and compared from 7 aspects. After that, an improved BP neural network was established to realize the construction and optimization of the constructed MAMS prediction model, and the effectiveness of the model was verified by experimental results from aspects of the training error curve trend, prediction evaluation classification, classification error size, and the accuracy of predicted category.

\section{$7 \quad$ Acknowledgement}

This research was supported by 2020 Visiting Engineers of Universities in China, University-Enterprise Cooperation Project (Grant No.: FG2020057), Education and Science Planning Commission Foundation, Zhejiang Province, China (Grant No.: 2019SCG215); Philosophy and Social Sciences Foundation of Wenzhou, China (Grant No.: 20wsk162). Wenzhou Polytechnic Teaching reform project (Grant No.: WZYZD202005).

\section{$8 \quad$ References}

[1] Kettler, E., Bieder, M. (2006). Occupational safety and health protection in modern power plant operation - New contents in the apprenticeship of a power plant master craftsman. VGB PowerTech, 86(7): 88-90+7.

[2] Yang, B. (2020). Training Model of Innovative Talents in Physical Education Major, International Journal of Emerging Technologies in Learning, 15(24), 176-190.

[3] Oehler, A., Höfer, A., Schalkowski, H. (2015). Entrepreneurial education and knowledge: empirical evidence on a sample of German undergraduate students. Journal of Technology Transfer, 40(3): 536-557. https://doi.org/10.1007/s10961-014-9350-2

[4] Gao, F., Zhang, P. (2020). Performance Evaluation of Industry-Education Integration in Higher Vocational Colleges:An Evidence from China, International Journal of Emerging Technologies in Learning, 15(23), 208-219. https://doi.org/10.3991/ijet.v15i23.19025

[5] Ma, J.H. (2017). Study on the e-commerce talent incubation based on modern apprenticeship and internet integration. Boletin Tecnico/Technical Bulletin, 55(16): 628-634.

[6] Diao, A.J. (2015). Vocational education modern apprenticeship development strategy research. 2015 International Conference on Intelligent Transportation, Big Data \& Smart City (ICITBS). https://doi.org/10.1109/icitbs.2015.251

[7] Truman, S.M., Truman, P.J. (2006). An investigation of the situated learnability effects of single- and dual-modal systems in education: A report of music-oriented learning environment and science computer-assisted teaching studies. British Journal of Educational Technology, 37(1): 131-142. https://doi.org/10.1111/j.1467-8535.2005.00533.x

[8] Fueredi, M. (1997). Educational Aspects and Structural Reform Efforts in the German Engineers' and Electrical Engineers' Education. Elektrotechnika, 90(7): 282. 
[9] Hansmann, W. (1997). Survey of computer graphics education at German universities. Computers and Graphics (Pergamon), 21(1): 113-116. https://doi.org/10.1016/s0097-8493 (96)00090-8

[10] Liu, X.L. (2017). Analysis on satisfaction degree of school-enterprise cooperation in application-oriented undergraduate base on two-dimensional scale. Boletin Tecnico/Technical Bulletin, 55(7): 92-97. https://www.learntechlib.org/p/217937/

[11] Li, Y.X., Hu, Z.H. (2014). The technological innovation study on cemented carbide enterprise based on school-enterprise cooperation. Fenmo Yejin Cailiao Kexue yu Gongcheng/Materials Science and Engineering of Powder Metallurgy, 19(6): 1006-1010.

[12] Cheng, S., Liu, H.Y. (2014). Improve combination of theory and practice in teaching and strengthen school-enterprise cooperative teaching mechanism. BioTechnology: An Indian Journal, 10(9): 4007-4012.

[13] Tao, Y.Q. (2013). The study of the cooperation evolution between school-enterprises on dynamic force model. Journal of Chemical and Pharmaceutical Research, 5(11): 254-259.

[14] Fujii, M., Kato, N., Shimizu, T., Satomi, K., Taguchi, S. (2007). Cooperation between an enterprise and a school in mechanical design education by using 3D-CAD. Nihon Kikai Gakkai Ronbunshu, C Hen/Transactions of the Japan Society of Mechanical Engineers, Part C, 73(1): 30-35. https://doi.org/10.1299/kikaic.73.30

[15] Wiemann, J. (2017). Export of German-style vocational education: A case study in the automotive industry in Puebla, Mexico. International Journal of Automotive Technology and Management, 17(2): 208-222. https://doi.org/10.1504/ijatm.2017.10005767

[16] Paton, R.A., Wagner, R. (2014). Management education makes a difference: Enhancing german engineering performance. Long Range Planning, 47(5): 277-298. https://doi.org/ $\underline{10.1016 / j .1 r p .2012 .06 .002}$

[17] Schavan, A. (2006). Preface: German federal ministry of education and research. Lecture Notes in Computer Science (including subseries Lecture Notes in Artificial Intelligence and Lecture Notes in Bioinformatics), v3995 LNCS, pVIII, Emerging Trends in Information and Communication Security - International Conference, ETRICS 2006, Proceedings. https:// doi.org/10.1007/11766155

[18] Bremer, F.J. (2000). Impact analysis of the materials research programmes "Matfo" and "MaTech" of the German Federal Ministry of Education and Research - BMBF extended summary of a study published in September 1999. Materials Research Innovations, 3(5): 246-249. https://doi.org/10.1007/s100190000045

[19] Neugebauer, J., Hubwieser, P., Magenheim, J., Ohrndorf, L., Schubert, S. (2014). Measuring student competences in german upper secondary computer science education. Lecture Notes in Computer Science (including subseries Lecture Notes in Artificial Intelligence and Lecture Notes in Bioinformatics), 8730: 100-111. https://doi.org/10.1007/978-3-319-099583_10

[20] Vossen, G. (2010). German informatics academy: Further education in informatics. Informatik-Spektrum, 33(1): 77-80. https://doi.org/10.1007/s00287-009-0415-9

[21] Susanne, V.Z. (2010). Speech and voice training for future teachers: The current situation in german higher education. L.O.G.O.S. Interdisziplinair, 18(1): 42-49.

[22] Griesbaum, J., Mahrholz, N., Kiedrowski, K.V.L., Rittberger, M. (2015). Knowledge generation in online forums: A case study in the German educational domain. Aslib Journal of Information Management, 67(1): 2-26. https://doi.org/10.1108/ajim-09-2014-0112

[23] Ratnasingam, J., Ioras, F. (2007). Sustaining the south east asian wood products sector through education: The German lesson. Journal of the Institute of Wood Science, 17(5): 254258. https://doi.org/10.1179/wsc.2007.17.5.254 
Paper-Evaluation of the Motivation Status of Enterprises and Higher Vocational Schools Participating...

\section{Authors}

Shu Ji, Research Direction: Higher education, Hospitality Management; Education: Master Degree-Changsha University of Science \& Technology, English Language and Literature; Work Experience: Lecturer at School of Humanity in Zhejiang Dongfang Polytechnic. Wenzhou 325000, China. (Email: jgh@zjbc.edu.cn)

Jun Li Research Direction: Higher education Industrial policy; Education: PhD Degree-Zhejiang Gongshang University, Business management; Work Experience: Vice professor at Business Administration Department in Wenzhou Polytechnic. Wenzhou 325035, China. (Email: wenzhi2017@wzvtc.edu.cn)

Article submitted 2021-02-17. Resubmitted 2021-03-04. Final acceptance 2021-03-06. Final version published as submitted by the authors. 